\title{
MINŐSÉGJELZŐS ÉLELMISZEREK HELYZETE ÉS KILÁTÁSAI MAGYARORSZÁGON - AZ EU BIOCÍMKE ESETE
}

\section{POSITION AND PROSPECTS OF QUALITY-LABELLED FOODS IN HUNGARY:} THE CASE OF THE EU ORGANIC LABEL

\begin{abstract}
A tanulmány az EU-s biotanúsító címke ismertségével, valamint a logó ismeretét és a rendszeres vásárlást meghatározó tényezőkkel foglalkozik a magyar fogyasztók körében. A több mint 1.000 fő bevonásával elvégzett felmérés adatain - a vonatkozó hazai és nemzetközi szakirodalom feldolgozását követően - a leíró statisztikai elemzéseken túl binomiális logisztikus regressziós elemzéseket végeztek a szerzők. Magyaroroszágon mind az organikus termelésbe vont földterületek aránya, mind pedig a bioélelmiszerek fogyasztása az Európai Unió 28 tagállamához viszonyítva meglehetősen alacsony. Nem meglepő, hogy az EU biocímke és bioélelmiszerek ismertsége a növekvő tendencia ellenére még mindig alacsonynak tekinthető. A kutatási eredmények alapján Magyarországon az EU biologó ismeretét főként a nem (férfi), az étrend (halfogyasztás, (ovo)-vegetáriánus) és a vásárlás helyszíne (alternatív úton és online) határozza meg. A rendszeres vásárlást tekintve a címkébe és a rendszerbe vetett bizalom kulcsfontosságú. Az EU biocímkével ellátott termékek eladásainak növeléséhez tehát elengedhetetlen a bioélelmiszerek nagyobb választékban és szélesebb körben történő értékesítése, amelynek köszönhetően a fogyasztók jobban megismerhetik a biotermékeket és a biologót, valamint a vállalatok által megfelelő marketingstratégia alkalmazása, amellyel elérhetik a potenciális célcsoportjukat, a fiatalabb korosztályokat.
\end{abstract}

Kulcsszavak: élelmiszerminőség, bioélelmiszer, EU biocímke, étrend, vásárlási helyszín

The aim of this study is to investigate the awareness of the Hungarian consumers about the EU organic label and the factors that determine the awareness of the EU organic logo and the regular purchases of such products. The survey conducted in Hungary is based on a sample with more than 1.000 consumer, and - after the systematic literature review - beyond descriptive statistical analysis the authors used binomial logistic regression models. In Hungary, both the proportion of land with certified organic production and the consumption of organic food in relation to the 28 member states of the European Union is rather low. Not surprisingly, the awareness of the EU organic label and organic food is still low despite the growing tendency in the recent years. The awareness of the EU organic logo is mainly determined by the sex (male), diet (fish consumption, (ovo)-vegetarian) and the place of purchase (alternative routes and internet). Regarding regular purchases, trust in the label and the system is crucial. Therefore, in order to increase the sales of products with EU organic label, it is essential to sell bio food more widely, that will enable consumers to know more about organic products and the EU organic logo; as well as the application of a proper marketing strategy by companies to reach their potential target group, mainly the younger consumers.

Keywords: food quality, organic food, EU bio label, course, place of purchase

\section{Finanszírozó/Funding:}

This paper is based on the Strength2Food project that has received funding from the European Union's Horizon 2020 research and innovation programme under grant agreement No 678024.

A tanulmány a Bolyai János Kutatási Ösztöndíj támogatásával készült.

Az Emberi Erőforrások Minisztériuma ÚNKP-18-4 kódszámú Új Nemzeti Kiválóság Programjának támogatásával készült. A publikációhoz tartozó kutatások elvégzését és a publikáció elkészítését az NKFIH FK124800 és PD124791 „Az élelmiszer minőségi rendszerek és rövid élelmiszer ellátási láncok gazdasági és társadalmi hatásai Magyarországon" című pályázat támogatta.

\section{Köszönetnyilvánítás/Acknowledgements:}

A szerzők ezúton szeretnének köszönetet mondani Ching-Hua Yeh-nek, a Bonni Egyetem munkatársának, a kérdőív összeállításában és a lekérdezés koordinálásában nyújtott szakmai segítségéért.

\section{Szerzők/Authors:}

Dr. Török Áron, egyetemi adjunktus, Budapesti Corvinus Egyetem (aron.torok@uni-corvinus.hu)

Jantyik Lili, PhD-hallgató, Budapesti Corvinus Egyetem (lili.jantyik@uni-corvinus.hu)

Maró Zalán Márk, egyetemi hallgató, Budapesti Corvinus Egyetem (zalan.maro@uni-corvinus.hu) 
A növényvédő szerek, a genetikailag módosított élölények és a különféle élelmiszerbiztonsággal kapcsolatos botrányok egészségre és környezetre gyakorolt hatásaira adott egyfajta válaszként a bioélelmiszerek iránti kereslet az elmúlt évtizedekben látványosan nőtt. A kínálati oldal is alkalmazkodik a fogyasztók új igényeihez, de az egyre inkább meghatározó hosszú ellátási láncok, valamint az élelmiszerek esetében különös jelentőségű információs aszimmetria megnehezíti a fogyasztók döntéshozatalát (lásd többek között: (Anania \& Nisticò, 2004; Andersen, 1994). Ennek javítása érdekében az élelmiszerágazatban megkerülhetetlenné váltak az élelmiszerek csomagolásán feltüntethető jelölések, amelyeknek köszönhetően az információs aszimmetria csökkenhet és a fogyasztók egyre tudatosabb élelmiszervásárlási döntéseket hozhatnak (Bonroy \& Constantatos, 2015).

Az organikus módon előállított biotermékek közösségi szabályozása 1991-ben született meg az Európai Unióban, a jelenleg is érvényben lévő szabályozás 2018-óta hatályos, s a biotermékek EU-s tanúsításaként szolgáló EU biologó (1. ábra) 2010-óta van forgalomban. (A továbbiakban EU biotanúsítással rendelkező termékek, illetve az EU biotermék és logó alatt az Európai Parlament és a Tanács 2018/848 rendeletének megfelelő termékeket és a tanúsítás vizuális megjelenítését értjük, továbbá a bio és öko megnevezést egymás szinonimájaként használjuk.)

A szabályozás lényege, hogy az EU biocímkét kötelezően fel kell tüntetni minden olyan elörecsomagolt ökológiai termelésből származó élelmiszeren, amelyet bioként kívánnak forgalomba hozni. Az EU-s jelölés használata ugyanakkor nem kizárólagos, amellett lehetőség van még különböző nemzeti és/vagy magán tanúsító szervezetek jelöléseit is feltüntetni. Magyarországon jelenleg két államilag akkreditált tanúsító szervezet foglalkozik az EU biocímke használati jogosultságának ellenőrzésével (a Biokontroll Hungária Nonprofit Kft. és a Hungária Öko Garancia Kft.). Mindkét szervezet rendelkezik saját logóval is, így a gyakorlatban - magyar eredetü biotermék esetén - az EU és az egyik magyar tanúsító logója egyszerre szerepel a tanúsított élelmiszer csomagolásán (1. ábra).

\section{1. ábra A Magyarországon leggyakrabban előforduló biocímkék}
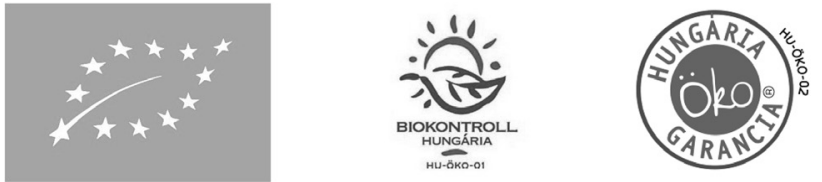

Megjegyzés: balról jobbra sorrendben az EU biologó, illetve a Biokontroll Hungária Nonprofit Kft. és a Hungária Öko Garancia Kft. védjegyei

Forrás: A bizottság 271/2010/EU rendelete, illetve a magyar tanúsító szervezetek honlapjai

Magyarországon a bioterületek aránya az EU-s átlaghoz képest nagyon alacsony (2. ábra), az Európai Unió 28 tagállama között csupán a 20. helyet foglalja el. Összhangban ezzel a biotermékek fogyasztása is igen alacsony (3. ábra), mindösszesen 3,04 EUR/fö/év, holott az európai átlag 50,12 EUR/fö/év. A két ábra alapján azt a következtetést vonhatjuk le, hogy azon országokban, ahol magas a bioterületek aránya az összterület-

hez viszonyítva, ott a fogyasztók magasabb összeget fordítanak bioélelmiszerre. Ez alól kivétel Luxemburg, ahol a bioterületek aránya elenyésző, azonban a 3. legnagyobb fogyasztó az Unión belül a fajlagos költéseket figyelembe véve (FiBL, 2019).

\section{2. ábra Az Európai Unió országaiban a bioterületek aránya (\%), 2016}

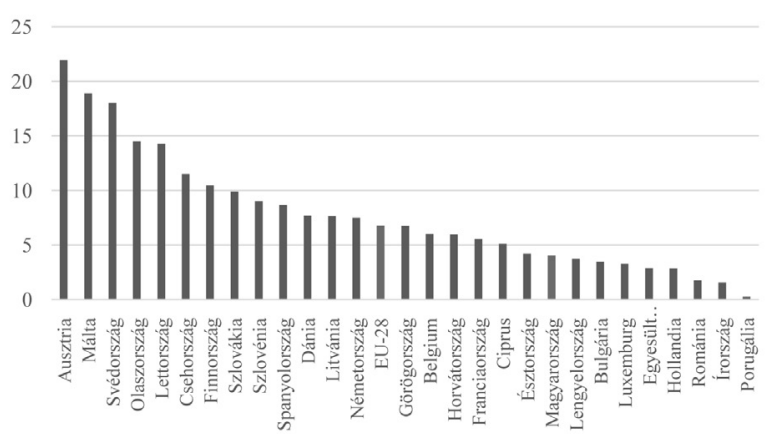

Forrás: saját szerkesztés FiBL (2019) adatok alapján

3. ábra Az Európai Unió országonkénti bioélelmiszer fogyasztása (EUR/fö/év), 2016

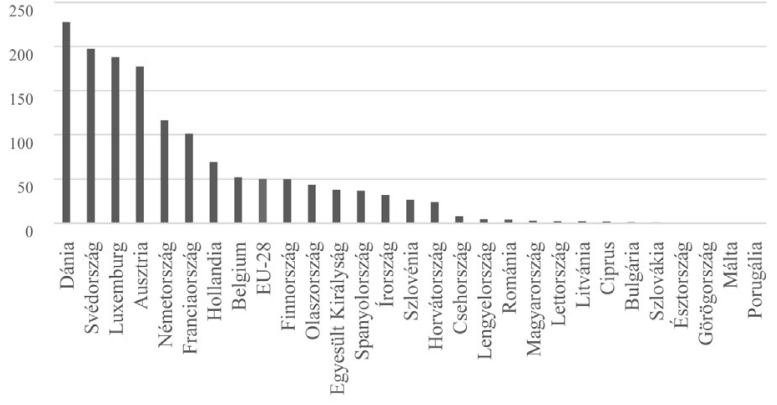

Forrás: saját szerkesztés FiBL (2019) adatok alapján

A 4. ábrán látható, hogy Magyarországon az organikus termesztésbe vont területek több mint fele rét, illetve legelö (KSH, 2019). Ebből az következik, hogy ezekről a területekről közvetlenül nem kerül biotermék a fogyasztók asztalára, azok csak alapanyagként szolgálnak a többi termelö ágazat számára. Azonban még inkább jellemző, hogy Magyarországon leginkább a támogatáshoz való könnyebb hozzáférés miatt szerzik meg a gazdák a biominősítést a területeikre.

\section{4. ábra A bioterületek megoszlása Magyarországon, 2016}

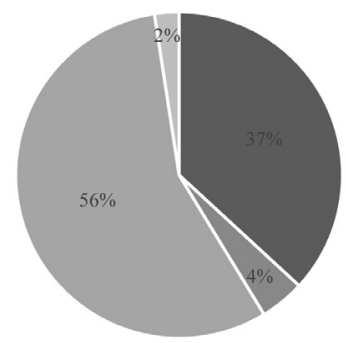

- Szántóföldi növények = Ültetvények = Rét, legelő " Ugar, zöldtrágya

Forrás: saját szerkesztés KSH (2019) adatok alapján 
A fentiek alapján a tanulmány kutatási kérdései több területet is vizsgálnak. Először is, az európai uniós bioélelmiszerek szabályozásának, illetve a tanúsított termékek vizuális megjelenítésének központi elemét képező EU biocímkét mennyire ismerik a magyar fogyasztók, illetve milyen véleménnyel vannak róla? Ilyen fókuszú, célzott vizsgálat a legjobb tudomásunk szerint Magyarországon mindezidáig nem készült; az Európai Bizottság által készített páneurópai felmérések (Európai Bizottság, 2012, 2014, 2016) csak a címke ismeretének tényét vizsgálják, annak mélyebb összefüggéseit nem.

Mindezeken túl ökonometriai módszerekkel vizsgáljuk, hogy az EU biocímke ismeretét, illetve az ilyen tanúsítással ellátott termékek rendszeres vásárlását milyen szocioökonómiai tényezők befolyásolhatják Magyarországon. A bioélelmiszerek fogyasztásának nemzetközi szakirodalma jelentős, az azokat szintetizáló szisztematikus szakirodalom-feldolgozások (többek között lásd: Schleenbecker \& Hamm, 2013; Fernqvist \& Ekelund, 2014; Hemmerling \& Hamm \& Spiller, 2015; Schäufele \& Hamm, 2017) alapján több megállapítás is tehető. Először is, a fogyasztók bioélelmiszerekkel kapcsolatos attitüdjeit leginkább az USA-ban, az Egyesült Királyságban és Olaszországban vizsgálták mindezidáig (Hemmerling et al., 2015), az ilyen fókuszú publikációk száma a kelet-közép-európai régióból elenyésző. Másodszor pedig az is egyértelmü, hogy a nemzetközi szakirodalomban leggyakrabban a nem, a családi állapot, az életkor, a képzettségi szint, a lakhely, illetve a jövedelem szerepét vizsgálja a bioélelmiszerekkel kapcsolatban. Felmérésünk alapján ezen túlmenően mi vizsgáljuk az étrend, illetve a tipikus vásárlási helyszín szerepét is.

Összességében tehát a tanulmányunk hozzájárul a magyar fogyasztók bioélelmiszerekkel kapcsolatos attitüdjeinek megértéséhez. A vizsgálatok alapját a nemzetközi szakirodalomban leggyakrabban megjelenő ismérveken túl újszerü tényezők bevonásával is elemezzük. Eredményeink elsősorban a szabályozói oldalnak, illetve a bioélelmiszereket kínáló vállalkozásoknak jelenthetnek segítséget annak megértésében, hogy a magyar fogyasztók hogyan viszonyulnak az EU biocímkével ellátott élelmiszerekhez.

\section{Szakirodalmi áttekintés}

Kutatásunkat a témával kapcsolatban korábban megjelent magyar nyelvü, illetve nemzetközi szakirodalom feltérképezésével kezdtük. A hazai szakirodalomban a legjobb tudomásunk szerint mindezidáig senki sem vizsgálta ilyen formában az EU biocímkéjével kapcsolatos társadalmi és gazdasági hatásokat, s ennek a kérdéskörnek az általános biovetületével is csak kevesen foglalkoztak. A magyar nyelvű szakirodalomban leginkább az egészségtudatos táplálkozással kapcsolatban (pl.: Gál, Soós \& Szakály, 2017; Hofer, 2009; Malota, Gyulavári \& Bogáromi, 2019), illetve a biocímkék, mint élelmiszer-minőségjelzők marketinglehetőségeihez kötődően (többek között: M. Kiss, Kontor \& Kun, 2016; Szabó, 2006) folytak kutatások. Annak érdekében tehát, hogy a magyar fogyasztók és az EU biocímke viszonyát megérthessük, érdemes nemzetközi kontextusba helyezni a témát.
Mivel egy olyan független tanúsításról van szó, amely vizuális megjelenéssel (EU biocímke) párosul, megkerülhetetlen a címkék ismertségének vizsgálata. Az egyik legrégebbi, ökológiai gazdálkodásból származó címkék ismertségét vizsgáló felmérés 1997-ben készült az Egyesült Királyságban. Hutchins \& Greenhalgh (1997) alapvetően különböző brit biotanúsítások ismeretét mérte a fogyasztók körében, s arra jutottak, hogy még a legismertebb címkével is kevesebb, mint minden tizedik brit fogyasztó van tisztában. Janssen \& Hamm (2012) ugyanakkor már az EU biocímke ismertségét is mérték egyes nemzeti tanúsítások mellett. A hat országban (Csehország, Dánia, Németország, Olaszország, Svájc és Egyesült Királyság) mért adatok alapján jelentős országok közötti eltérés volt megfigyelhető. A kutatásból kiderül, hogy az EU biocímkét ismerők aránya magasan Olaszországban a legnagyobb (közel 80\%) és az Egyesült Királyságban a legalacsonyabb (körülbelül 10\%). Továbbá az is kiemelendő, hogy a felmérés szerint a nemzeti tanúsítások ismertsége az országok többségében jelentősen meghaladta az EU közösségi jelölésének ismertségét. Zander (2014) hat országban (Észtország, Franciaország, Németország, Olaszország, Lengyelország és Egyesült Királyság) 3000 fogyasztó megkérdezésével mérte fel az általunk is vizsgált EU biologó ismertségét, a biotermesztéshez való hozzáállást, a biofogyasztók vásárlási szokásait és a fogyasztók szocio-demográfiai tulajdonságait. Az eredmények alapján, a logó ismerete alacsony, továbbá a válaszadók mindössze 15\%-a tudta a logó jelentését. A bináris logisztikus regresszió azt mutatta, hogy a címke ismerete magasabb azoknál a fogyasztóknál, akik rendszeresen vásárolnak ökológiai élelmiszereket. Az uniós logó ismeretének valószínűsége a legmagasabb Észtországban és Lengyelországban volt.

Az EU biocímke ismertségét az Európai Bizottság is több alkalommal mérte. Ahogyan azt az 5. ábra is mutatja, egész Európára nézve alig minden negyedik ember ismeri csak ezt a tanúsítást, s Magyarországon ezek az értékek rendre elmaradnak még ettől az átlagtól is.

\section{5. ábra A biocímke ismertsége az EU-ban és Magyarországon}

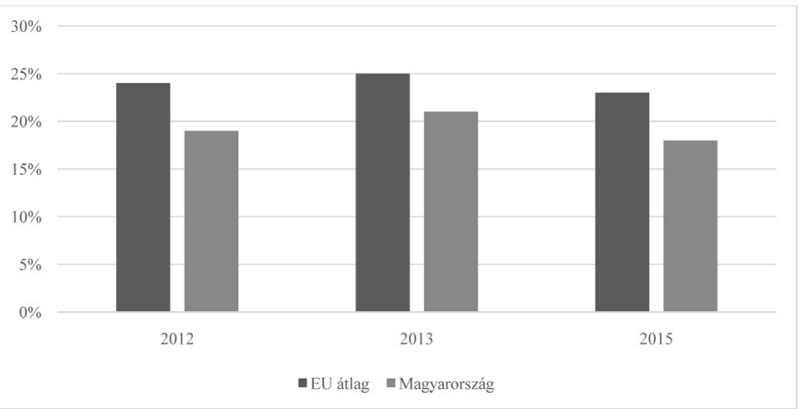

Forrás: saját szerkesztés Európai Bizottság (2012,2014 és 2015) alapján

Mivel a bio/organikus módon előállított élelmiszerek meghatározása nem egységes (a közösségi szabályozás 1991-es bevezetéséig az EU-ban sem volt az), a világ különböző részein, más-más módon szabályozzák az elne- 
vezéseket. Ez a fajta különbözőség értelemszerűen a fogyasztók fejében is egyfajta zavart okoz. A szakirodalmi feltárások alapján a fogyasztók leginkább azért vásárolnak bioélelmiszereket, mert azok szerintük biztonságosabbak, egészségesebbek és környezetbarátabbak, mint a nem organikus módon előállított élelmiszerek (Yiridoe, Bonti-Ankomah \& Martin, 2005). Hofer (2009) arra hívja fel a figyelmet, hogy a bioélelmiszerek fogyasztásának oka az egészség védelme mellett a betegségek megelőzése is; ezáltal megfelelően kiválasztott marketingeszközök használatával növelhető az eladások száma, amely a jövedelmezőség és versenyképesség javulásához vezethet.

Mivel az élelmiszerek, de különösen a bioélelmiszerek, bizalmi jószágnak tekinthetők, ezért az adott termék organikus tulajdonságainak meglétét, vagy éppen hiányát a fogyasztók sokszor még a megvásárlás után sem tudják érzékelni. Az emiatt fellépő információs aszimmetria csökkentésére szolgáló tanúsítás fogyasztó számára is érzékelhető meglétét testesítik meg az élelmiszerek csomagolásán szereplő címkék (Giannakas, 2002). Éppen ezért fontos megvizsgálni a fogyasztók biocímkékbe vetett bizalmát is. A címkéket különböző állami szervek és akkreditált vállalkozások felügyelik. Aarset et al. (2004) öt európai országban végzett kutatása szerint a szabályozási folyamatok iránti bizalom országonként jelentős eltérést mutathat. Sønderskov \& Daugbjerg (2011) négy országban (három EU-tagállamban és az USA-ban) vizsgálta a biocímkék megbízhatóságát. Megállapították, hogy a különböző ökológiai címkézési rendszerekbe vetett bizalom akkor a legnagyobb, ha jelentős benne az állami szerepvállalás. Bruschi et al. (2015) Oroszországban vizsgálódott hasonló témában, s elemzésükből kiderül, hogy a megkérdezettek nem igazán bíznak az élelmiszercímkék rendszerében, ugyanakkor a külföldi tanúsítások elfogadottsága magasabb, mint a hazai (orosz) tanúsítóké. Magyarországon a bizalomhiány járul hozzá nagyban ahhoz, hogy a fogyasztás ilyen alacsony nemcsak európai, hanem régiós mércével vizsgálva is (Hofer, 2009). Összességében tehát a különféle (bio)tanúsításokba vetett bizalom meglehetősen változó képet mutat, holott a bioélelmiszerek jellegéből fakadóan a bizalom kérdése kulcsfontosságú tényező.

A szakirodalom igen jelentős része azzal foglalkozik, hogy megpróbálja beazonosítani a bioélelmiszereket vásárló fogyasztók legfontosabb szocio-demográfiai és -ökonómiai jellemzőit.

Az egyik leggyakrabban vizsgált ismérv a nemek szerepe, s a kutatások eredményeinek döntő többsége azt támasztja alá, hogy alapvetően a nők preferálják jobban az ökológiai termesztésből származó élelmiszereket a konvencionális termékekkel szemben (Koivisto Hursti \& Magnusson, 2003; Lea \& Worsley, 2005; Lockie et al., 2002; Magnusson et al., 2003; Magnusson et al., 2001; Stobbelaar et al., 2007). Egyesek ennél továbbmenve azt is megállapítják, hogy a nők gyakrabban is vásárolják a bio termékeket (Barber, Taylor \& Deale, 2010; Davies, Titterington \& Cochrane, 1995; Lockie et al., 2002; Loureiro, 2003; Mann, Ferjani \& Reissig, 2012; McEachern \& McClean, 2002; O'Donovan \& McCarthy, 2002; Pomarici
\& Vecchio, 2014; Radman, 2005; Storstad \& Bjørkhaug, 2003; Vecchio, 2013). Ennek ugyanakkor ellentmond Wandel \& Bugge (1997), akik szerint a férfiak hajlandóak magasabb árat fizetni a biotermékekért.

A nemek szerepén túl nagy a jelentősége a család méretének és a gyerekek számának. Több tanulmányból is kiderül, hogy az olyan családok, ahol gyermek is van, nagyobb valószínüséggel választanak ökológiai címkével ellátott terméket (Davies et al., 1995; Gergely, Szabó \& Balázs, 2014; McEachern \& Willock, 2004; Szente, 2004; Thompson \& Kidwell, 1998). Gyakran a gyerek születése az, ami kiváltja a szülőkből a biotermékek iránti érdeklödést (Hill \& Lynchehaun, 2002). Emellett a bioélelmiszerek fogyasztását pozitív irányba befolyásolhatja a közeli ismerösök ajánlása az egyén közvetlen környezetéből (Panyor, 2010).

Az életkor tekintetében egymásnak ellentmondó eredmények születtek a szakirodalomban. Néhány kutatás az idősebb korosztályokat találta fogékonyabbnak a biotermékek vásárlására (Roddy, Cowan \& Hutchinson, 1996; Schifferstein \& Oude Ophuis, 1998); ugyanakkor ezzel ellenkező eredmények is napvilágot láttak a közelmúltban, miszerint a fiatalabb korosztályok nagyobb valószínűséggel vásárolnak biotermékeket (Magnusson et al., 2001; Szente, 2004). Ez egyben azt is sugallja, hogy az ezredforduló után egyre inkább a fiatalabb vásárlók váltak a biotermékek jellemző fogyasztóivá. Zander (2014) kutatásában is a fiatalabb fogyasztók ismerték jobban az EU biocímkét. Mindezek mellett, olyan vizsgálatok is készültek, amelyekben a szerzők nem találtak kapcsolatot a kor és a biotermékek iránti vásárlási hajlandóság között (Davies et al., 1995; Fotopoulos \& Krystallis, 2002b; Lea \& Worsley, 2005; O'Donovan \& McCarthy, 2002). Azt azonban mindenképpen meg kell jegyezni, hogy a jövőben a fiatalabb korosztályoknak nagy hatása lesz a bioélelmiszerek fogyasztására, ugyanis ők már gyerekkoruk óta hallanak a bioélelmiszerekröl és azok pozitív hatásáról (Gergely et al., 2014).

A képzettség vizsgálatánál hasonlóan ellentmondásos eredmények találhatóak a szakirodalomban. Néhány szerző pozitív kapcsolatot talált a képzettség és a biotermékek vásárlása, illetve ismertsége között (O'Donovan \& McCarthy, 2002; Sandalidou, Baourakis \& Siskos, 2002; Wandel \& Bugge, 1997; Zander, 2014), ugyanakkor voltak, akik ennek az ellenkezőjére jutottak (Thompson \& Kidwell, 1998; Wilkins \& Hillers, 1994). Olyan tanulmányok is születtek, ahol nem találtak összefüggést a két ismérv között (Lea \& Worsley, 2005).

A vásárlók lakóhelyét vizsgálva a korábbi szakirodalom szerint a városi környezetben élő emberek jobban érdeklődnek a különböző fenntarthatósággal kapcsolatos jellemzők, így a biotermékek iránt is (Mann et al., 2012; Pomarici \& Vecchio, 2014; Szente, 2004).

Végezetül pedig számos tanulmány pozitív összefüggést mutatott az ökológiai termékek vásárlási valószínüsége, az árprémiumok elfogadása és a jövedelmi szint között (Davies et al., 1995; Fotopoulos \& Krystallis, 2002a; Hill \& Lynchehaun, 2002; Loureiro, 2003; O'Donovan \& McCarthy, 2002; Sandalidou et al., 2002; Szente, 2004). 
Ugyanakkor olyan, jellemzően régebbi tanulmányok is megjelentek, amelyek szerint a jövedelem nem szignifikánsan magyarázza az ökológiai termékek vásárlását (Goldman \& Clancy, 1991; Wilkins \& Hillers, 1994).

Magyarországon - ahogy szerte Európában - a bioélelmiszerek a fogyasztók mindennapjainak részévé válnak, ugyanis egyre nagyobb választékban érhetők el (Dörnyei, 2008). A fogyasztók egyre szélesebb ismerettel rendelkeznek e termékekről, ideértve főbb jellemzőiket és hatásukat (Szente, 2004, 2009), amelyben elengedhetetlen szerepe volt hazánkban a biotermékek hiper-, illetve szupermarketekben való megjelenésének (Horváth, Kovács \& Gyenge, 2003), valamint az internet elterjedésének (Podruzsik \& Hegede, 2019). A bioélelmiszerek fogyasztását még inkább növelheti, hogy egyre többen tartják fontosnak az egészséges táplálkozást (Dörnyei, 2008; Hofer, 2009; C. Kiss et al., 2005), azonban a magyar fogyasztók továbbra sem tekinthetők teljesen tudatosnak a vásárlás terén, melynek köszönhetően valószínütlen, hogy az bioélelmiszerek tömegcikké váljanak a közeljövőben, ezért a termékek réspiaci jellegét érdemesebb erősíteni (Szente, 2004). A magyar fogyasztók biotermékként legfőképpen zöldséget, gyümölcsöt, kenyeret és tejterméket vesznek, elsősorban hipermarketekben és piacokon, míg a tipikus magyar bioélelmiszer-fogyasztó elsősorban magasan képzett és magasabb jövedelemmel rendelkező, gyermekeket nevelő nő (Dörnyei, 2008), míg a vásárlási csatornákat tekintve az ezredforduló utáni években a biopiacok - azok közül is a budapesti Csörsz utcai ökopiac -, valamint a hiper- és szupermarketek voltak a leginkább meghatározók (Szente, 2005, 2006).

Összességében tehát megállapítható, hogy a biotermékek szocio-demográfiai és -ökonómiai jellemzői között nagy eltérések mutatkozhatnak mind térben, mind pedig időben. A korábbi szakirodalom célzott áttekintése után pedig általánosságban az állapítható meg, hogy a biotermékeket alapvetően a nők, a családosok (gyerekkel rendelkezők), a városban élők és a magasabb jövedelemmel rendelkezők preferálják.

\section{Adatok és módszertan}

A tanulmányban felhasznált adatok online lekérdezése 2017 második felében történt, a Strength2Food H2020 nemzetközi kutatás keretein belül (Magyarország mellett hat további európai országban), a LighSpeed Research piackutató vállalat bevonásával. A nemzetközi kutatócsoport által előzetesen elkészített, tartalmilag minden országban azonos kérdöívek lekérdezése online módon történt meg, kiértékelésük a kutatási projekt keretében központilag, illetve az országspecifikus összefüggések tekintetében országonként valósult meg (Hartmann et al., 2018).

Az 1. táblázat foglalja össze a válaszadók legfontosabb ismérveit. A több mint 1.000 fő bevonásával elvégzett magyar felmérés adataiból az adattisztítás után 875 választ értékeltünk ki. A nem magyarországi állandó lakhellyel rendelkező, továbbá az élelmiszer vásárlásért egyáltalán nem felelős válaszadók válaszait, illetve a hiányosan kitöltött kérdöíveket nem vettük figyelembe. A reprezentativitást tekintve elmondható, hogy a nem és az életkor tekintetében a minta közel reprezentatív, ugyanakkor a lakóhely esetében a községből származó válaszadók alul-, míg a legmagasabb iskolai végzettség esetében a magasabban képzettek felülreprezentáltak. Ez utóbbiakat leginkább a lekérdezés online volta magyarázza. Továbbá a mintán jelentős torzítás figyelhető meg a gyerekek számában: a kérdőívet kitöltők jelentősen kevesebb gyerekkel rendelkeztek, mint a magyarországi átlag.

1. táblázat A felmérésben részt vevő válaszadók legfontosabb szocio-demográfiai és -ökonómiai ismérvei

\begin{tabular}{|c|c|c|}
\hline & Felmérés & KSH népszámlálás \\
\hline Összes válaszadó/Népesség & 1019 & 9937628 \\
\hline Bevont válaszadó & 875 & - \\
\hline \multicolumn{3}{|l|}{ Nem } \\
\hline Nö (\%) & 50,03 & 52,52 \\
\hline Férfi $(\%)$ & 49,97 & 47,48 \\
\hline Átlagos életkor (év) & 41,93 & 41,39 \\
\hline \multicolumn{3}{|l|}{ Lakóhely } \\
\hline Község (\%) & 20,35 & 30,53 \\
\hline Város (\%) & 37,94 & 34,35 \\
\hline Nagyváros (\%) & 41,71 & 35,13 \\
\hline \multicolumn{3}{|l|}{ Végzettség } \\
\hline Általános iskola 8. évfolyam, vagy annál alacsonyabb (\%) & 2,63 & 31,73 \\
\hline Gimnázium, szakközépiskola, szakiskola, egyéb nem felsőfokú végzettség (\%) & 55,89 & 51,31 \\
\hline Főiskola, alapszakos diploma (\%) & 29,14 & 10,10 \\
\hline Egyetem, mester diploma, PhD. (\%) & 12,34 & 6,68 \\
\hline Háztartás átlagos jövedelme (Ft) & 255694 & $222097^{*}$ \\
\hline Gyerekek száma (fö) & 0,66 & 1,07 \\
\hline
\end{tabular}

* a népszámlálási adat korrigálva a fogyasztói árindexekkel

Forrás: saját szerkesztés a felmérés és KSH (2013) adatok alapján 
A leíró statisztikai elemzéseken túl binomiális logisztikus regressziót futtattunk annak érdekében, hogy megértsük, hogy a magyar fogyasztók esetében mi magyarázhatja azt, hogy valaki ismeri-e az EU biocímkét, illetve rendszeres vásárlója-e az ilyen tanúsítással ellátott termékeknek. A feltárt szakirodalom által korábban vizsgált paraméterek függvényében hat szocio-demográfiai és -ökonómiai változót (nem, gyerekek száma, életkor, képzettség, lakóhely, jövedelem) vizsgáltunk a saját mintánkon, továbbá két korábban nem vizsgált ismérvet, a tipikus vásárlás helyszínét, illetve az étrendet is bevontuk a modellbe (2. táblázat). Mindezeken túl a rendszeres vásárlók vizsgálatánál teszteltük, hogy a címke jelentéstartalmának ismerete, illetve a tanúsításba vetett bizalom milyen hatással van arra, hogy valaki rendszeres biovásárlóvá váljon.

2. táblázat A felmérésben részt vevő válaszadók egyéb ismérvei

\begin{tabular}{|l|c|}
\hline \multicolumn{2}{|c|}{ Étrenddel kapcsolatos ismérvek (\%) } \\
\hline Fogyaszt valamilyen tejterméket & 95,43 \\
\hline Fogyaszt halat & 62,97 \\
\hline Fogyaszt valamilyen húsfélét & 92,57 \\
\hline Fogyaszt tojást & 93,49 \\
\hline A leggyakoribb három élelmiszervásárlási helyszín (\%) \\
\hline Szupermarket & 70,2 \\
\hline Élelmiszer diszkont & 19,0 \\
\hline Kisbolt & 43,3 \\
\hline Termelői piac & 38,4 \\
\hline Áruház & 23,2 \\
\hline Hipermarket & 43,4 \\
\hline Biobolt & 5,3 \\
\hline Online vásárlás & 4,5 \\
\hline Közvetlenül a termelőtől & 14,4 \\
\hline Egyéb, alternatív csatorna & 1,3 \\
\hline
\end{tabular}

Forrás: saját szerkesztés a felmérés alapján

Ezek alapján a logisztikus regressziós modellek az alábbiak szerint épülnek fel:

$\operatorname{Pr}($ Ismeri az EU biocímkét $=1)=\mathrm{F}\left(\beta_{0}+\beta_{1}\right.$ Nem + $\beta_{2}$ Gyerekek száma $+\beta_{3}$ Életkor $+\beta_{4}$ Képzettség $+\beta_{5}$ Lakóhely $+\beta_{6}$ Jövedelem $+\beta_{7_{1-}{ }_{16}}$ Vásárlási helyszín $+\beta_{17-20}$ Étrend $)$, illetve

$\operatorname{Pr}($ Rendszeres vásárló $=1)=\mathrm{F}\left(\beta_{0}+\beta_{1} \mathrm{Nem}+\beta_{2}\right.$ Gyermekek száma $+\beta_{3}$ Életkor $+\beta 4$ Képzettség $+\beta_{5}$ Lakóhely + $\beta_{6}$ Jövedelem $+\beta_{7-16}$ Vásárlási helyszín $+\beta_{17-20}$ Étrend + $\beta_{21}$ Ismeret $+\beta_{22}$ Bizalom).

Az egyes változók részletes bemutatását a 3. táblázat ismerteti.
Összességében a tanulmány az alábbi kérdésekre keresi a választ:

- A magyar fogyasztók hogyan viszonyulnak az EU-s biocímkéhez? Mennyire ismerik azt, illetve milyen véleménnyel vannak róla?

- Milyen vásárlási attitüdökkel rendelkeznek a magyar fogyasztók az EU-s biotanúsítással és az ilyen termékekkel kapcsolatban? Vásárláskor figyelembe veszike ezt a jelölést, illetve vásárolják-e és mit vásárolnak?

- Milyen tényezők vannak arra hatással, hogy egy magyar fogyasztó ismeri-e az EU biotanúsítást? A nemzetközi szakirodalom által leggyakrabban vizsgált ismérvek (nem, gyerekek száma, életkor, képzettség, lakóhely, jövedelem), továbbá a tipikus vásárlási helyszín és az étrend meghatározó-e a magyarországi fogyasztók esetében?

- Mi jellemzi azokat a magyar fogyasztókat, akik rendszeresen vásárolnak EU biotanúsítással rendelkező termékeket? Az ismeretnél vizsgált ismérveken túl az EU-s tanúsítás jelentéstartalmának ismerete, továbbá az abba vetett bizalom meghatározó-e a magyarországi fogyasztók esetében?

\section{Eredmények}

A 6. ábrán jól látható - megerősítve az előzetes várakozásokat -, hogy a válaszadók közel egynegyede ismeri az EU biocímkét, hasonlóan a korábbi felmérések alacsony eredményeihez.

\section{6. ábra Az EU biocímkével kapcsolatos ismerete a meg-} kérdezettek körében

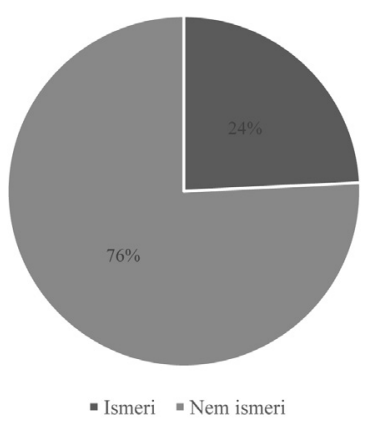

Forrás: saját szerkesztés a felmérés alapján

3. táblázat A modellekbe bevont változók

\begin{tabular}{|c|c|}
\hline Ismeri az EU biocímkét & Értéke 1, amennyiben a válaszadó azt állítja, hogy ismeri a címkét, egyébként 0 \\
\hline Rendszeres vásárló & Értéke 1, amennyiben a fogyasztó a lekérdezést megelőző 2 hétben is vásárolt ilyen terméket, egyébként 0 \\
\hline Nem & Értéke 1, amennyiben a válaszadó nő, egyébként 0 \\
\hline Gyermekek száma & A válaszadó háztartásában élő 18 éven aluli gyermekek száma \\
\hline Életkor & A válaszadó életkora \\
\hline Képzettség & $\begin{array}{l}\text { A válaszadó legmagasabb iskolai végzettsége (általános iskola 8. évfolyam, vagy annál alacsonyabb/gimnázium, } \\
\text { szakközépiskola, szakiskola, egyéb nem felsőfokú végzettség/főiskola, alapszakos diploma/egyetem, mester diploma, PhD) }\end{array}$ \\
\hline Lakóhely & A válaszadó lakóhelye (község/város/nagyváros) \\
\hline Jövedelem & A vásárló háztartásának együttes havi jövedelmi kategóriája (ezer HUF: <150; 150-205; 205-235; 235-380; 380-835; 835>) \\
\hline Vásárlási helyszín1-10 & $\begin{array}{l}\text { A leggyakoribb élelmiszer vásárlási helyszín (szupermarket, diszkont, kisbolt, termelöi piac, áruház, hipermarket, } \\
\text { biobolt, internet, közvetlenül a termelőtől, egyéb alternatív) }\end{array}$ \\
\hline Étrend1-4 & A válaszadó étrendje (Fogyaszt valamilyen: tejterméket/halat/hústerméket/tojást) \\
\hline Ismeret & $\begin{array}{l}\text { Értéke } 1 \text {, amennyiben a válaszadó tíz állításból ki tudott választani legalább egy olyat, ami azt a címkét helyesen } \\
\text { definiálja, egyébként } 0\end{array}$ \\
\hline Bizalom & Értéke 1, amennyiben a válaszadó szerint az EU biocímke megbízható, egyébként 0 \\
\hline
\end{tabular}

Forrás: saját szerkesztés 
A megkérdezettekről általánosságban elmondható, hogy összességében pozitív véleménnyel vannak a biocímkével kapcsolatban. Az ötfokozatú Likert-skálán a legmagasabb átlag 4,02 volt, amely azt mutatja, hogy a válaszadók megbízhatónak találják a címkét. Ez kiemelendő annak függvényében, hogy a (bio)élelmiszerek alapvetően bizalmi termékek. Emellett a logót könnyen értelmezhetőnek is vélik. A legalacsonyabb értéket $(3,37)$ a bio- és konvencionális termékek árának hasonlóságánál láthatjuk, amely azt jelenti, hogy a válaszadók többsége különbséget érzékel a logóval ellátott és logó nélküli termékek árai között (4. táblázat).

4. táblázat A megkérdezettek EU biocímkéről való véleménye

\begin{tabular}{|l|r|}
\hline Címkével kapcsolatos megállapítás & Átlag \\
\hline Ezt a jelölést könnyü értelmezni & 3,89 \\
\hline Ennek a jelölésnek érthető a logója/szimbóluma & 3,88 \\
\hline Ez a jelölés megbízható & 4,02 \\
\hline A jelölésen lévő szöveget könnyü elolvasni & 3,94 \\
\hline A jelölés segít abban, hogy egy tájékozott döntést hozzunk & 3,88 \\
\hline $\begin{array}{l}\text { A jelölt és jelöletlen termékeknek árai hasonlóak } \\
\text { egymáshoz }\end{array}$ & 3,37 \\
\hline A jelölés többet jelent, mint szimpla reklám & 3,74 \\
\hline Ez a jelölés megnyerő & 3,47 \\
\hline
\end{tabular}

Megjegyzés: a válaszadás egy 1-től 5-ig terjedő Likertskálán volt lehetséges, ahol az 1 azt jelentette, hogy a válaszadó az adott állítással egyáltalán nem értett egyet, míg 5 azt jelentette, hogy teljesen egyetért azzal.

Forrás: saját szerkesztés a felmérés alapján

A 7. ábra alapján a válaszadók döntő hányada (62\%) a vásárláskor csak ritkán veszi figyelembe, hogy az adott termék el van-e látva EU biologóval. A megkérdezettek mindösszesen $2 \%$-áról mondható el, hogy a vásárlás során rendszeresen nyomon követi melyik terméken található EU-s biocímke.

\section{7. ábra Az EU biocímke vásárláskor való figyelembevétele}

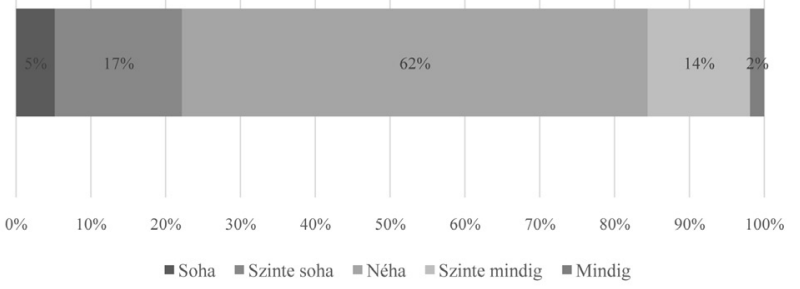

Megjegyzés: a kérdés csak azoknak a válaszadóknak lett feltéve, akik korábban azt mondták, hogy ismerik a címkét. Forrás: saját szerkesztés a felmérés alapján

Azon megkérdezettek többsége, akik ismerik a jelölést - de nem veszik figyelembe a logót döntéshozataluknál arra hivatkoztak leginkább, hogy nem fordítanak figyelmet az élelmiszer-vásárlás során a jelöléssel rendelkező termékekre. Emellett a vásárlóknak nincs elég idejük a biocímkével ellátott élelmiszerek jelölésével foglalkozni (5. táblázat).
5. táblázat Az EU biocímke vásárlási döntéseknél való mellőzésének leggyakoribb indokai

\begin{tabular}{|l|r|}
\hline \multicolumn{1}{|c|}{ Indok } & $\begin{array}{c}\text { Említési } \\
\text { gyakoriság }\end{array}$ \\
\hline $\begin{array}{l}\text { Ritkán fordítok figyelmet élelmiszer bevásárlása során a } \\
\text { jelöléssel rendelkezó termékekre }\end{array}$ & $30 \%$ \\
\hline Vásárlás során nincs időm a jelölésekkel foglalkozni & $18 \%$ \\
\hline Általánosságban nem hiszek a jelölésekben & $7 \%$ \\
\hline $\begin{array}{l}\text { Kevés a jelöléssel rendelkező termékek választéka a } \\
\text { boltban, ahol vásárolok }\end{array}$ & $7 \%$ \\
\hline Az üzenet, amit ez a jelölés hirdet, nem fontos számomra & $7 \%$ \\
\hline $\begin{array}{l}\text { Nem tudom, hogy hol keressem az ezzel a jelöléssel } \\
\text { ellátott termékeket }\end{array}$ & $7 \%$ \\
\hline
\end{tabular}

Megjegyzés: a kérdés csak azoknak a válaszadóknak lett feltéve, akik korábban azt mondták, hogy ismerik a címkét, azonban azt soha, vagy szinte soha nem veszik figyelembe a vásárláskor.

Forrás: saját szerkesztés a felmérés alapján

A legnépszerűbb címkével ellátott termékek (6. táblázat) a friss gyümölcs- és zöldségfélék (13\%), megelőzve a gabonatermékeket (11\%), emellett kedvelt termékcsoportok még a liszt és gabonafélék (8\%), a méz (8\%), a feldolgozott húsok (7\%) és az egyéb termékek (7\%). A friss gyümölcsés zöldségfélék első helye meglepő annak függvényében, hogy a magyarországi bioterületek csupán 2\%-a ültetvény, és a szántóföldi növénytermesztésben sem a friss zöldségfélék dominálnak, tehát itt az import szerepe megkérőjelezhetetlen. Ez az eredmény összhangban van korábbi felmérések eredményeivel is (Dörnyei, 2008).

6. táblázat A leggyakrabban vásárolt EU biocímkével rendelkező termékcsoportok a megkérdezettek körében

\begin{tabular}{|l|r|}
\hline Termékcsoport & $\begin{array}{l}\text { Említési } \\
\text { gyakoriság }\end{array}$ \\
\hline Friss gyümölcs-, zöldségfélék & $13 \%$ \\
\hline Gabonatermékek (kenyér, gabonapehely, rizs, tészta stb.) & $11 \%$ \\
\hline Liszt és gabonafélék & $8 \%$ \\
\hline Méz & $8 \%$ \\
\hline Feldolgozott hús (sonka, kolbász, füstölt hús stb.) & $7 \%$ \\
\hline Egyéb tejtermékek (joghurt, túró stb.) & $7 \%$ \\
\hline
\end{tabular}

Megjegyzés: a kérdés csak azoknak a válaszadóknak lett feltéve, akik korábban azt mondták, hogy figyelembe veszik a vásárlásaikkor a címkét és az elmúlt két hétben vásároltak EU biocímkével tanúsított élelmiszert.

Forrás: saját szerkesztés a felmérés alapján

A válaszadók nagy része (44\%) azért mellőzte a biotermékeket a vásárlás során, mert nem volt lehetősége EU-s biotanúsítvánnyal rendelkező élelmiszert vásárolni, vagy kis választékban voltak elérhetők abban a boltban, ahol az élelmiszerbeszerzést bonyolítja le (7. táblázat). Mindez azt bizonyítja, hogy Magyarországon a biotermékek kínálata ugyan növekszik, azonban jelenleg még mindig kevés boltban, és viszonylag kis választékban állnak rendelkezésre - a konvencionális élelmiszerekhez képest. A válaszadók nem fordítanak kellő figyelmet és időt az élelmiszereken található jelölések tanulmányozására. 
7. táblázat EU biotanúsítással rendelkező termékek vásárlási mellőzésének leggyakoribb indokai

\begin{tabular}{|l|r|}
\hline \multicolumn{1}{|c|}{ Indok } & $\begin{array}{c}\text { Említési } \\
\text { gyakoriság }\end{array}$ \\
\hline Nem volt lehetőségem az elmúlt 2 hétben & $24 \%$ \\
\hline $\begin{array}{l}\text { Kevés a jelöléssel rendelkező termékek választéka a } \\
\text { boltban, ahol vásárolok }\end{array}$ & $20 \%$ \\
\hline Vásárlás során nincs időm a jelölésekkel foglalkozni & $11 \%$ \\
\hline $\begin{array}{l}\text { Ritkán fordítok figyelmet élelmiszer bevásárlása } \\
\text { során a jelöléssel rendelkező termékekre }\end{array}$ & $10 \%$ \\
\hline $\begin{array}{l}\text { Nem tudom, hogy hol keressem az ezzel a jelöléssel } \\
\text { ellátott termékeket }\end{array}$ & $9 \%$ \\
\hline Ezzel a jelöléssel jelzett termékek túl drágák & $8 \%$ \\
\hline
\end{tabular}

Megjegyzés: a kérdés csak azoknak a válaszadóknak lett feltéve, akik korábban azt mondták, hogy figyelembe veszik a vásárlásaikkor a címkét, azonban és az elmúlt két hétben nem vásároltak EU biocímkével tanúsított élelmiszert.

Forrás: saját szerkesztés a felmérés alapján

A szocio-demográfiai ismérvek közül felmérésünkben egyedül a válaszadó neme volt statisztikailag szignifikáns, ez alapján pedig megállapítható, hogy a férfiak jobban ismerik a címkét, mint a nők. A címke ismeretéhez számottevően az járul hozzá, hogy az adott fogyasztó milyen beszerzési csatornán keresztül vásárolja meg az EU-s biocímkével ellátott terméket. A címkét azok a fogyasztók ismerik jobban, akik leginkább termelői piacokon, áruházakban, bioboltokban, online, közvetlenül a termelötől, vagy pedig egyéb, alternatív csatornákon keresztül vásárolnak élelmiszert. Ezek közül a leginkább meghatározó az egyéb alternatív csatornákon keresztül történő vásárlás, hiszen ötször nagyobb az esélye annak, hogy aki ilyen csatornán keresztül vásárol, az ismeri az EU biocímkét. Érdekesség, hogy a bioboltban vásárlás kisebb mértékben határozza meg a címke ismeretét, mint az interneten keresztül történő vásárlás. A rendszeresen halat fogyasztók majdnem kétszer jobban ismerik a logót, mint akik nem esznek halat, valamint az (ovo-)vegetáriánusok jobban ismerik a címkét, mint a nem (ovo-)vegetáriánusok (8. táblázat).

8. táblázat A címke ismeretét meghatározó tényezők

\begin{tabular}{lll}
\hline $\begin{array}{l}\text { Ismeri az EU } \\
\text { biocímkét }\end{array}$ & Nem & $\begin{array}{l}0,660 \\
(2,33)^{* *}\end{array}$ \\
& Termelői piac & 1,716 \\
& & $(2,49)^{* *}$ \\
& 1,661 \\
& Áruház & $(2,14)^{* *}$ \\
& Biobolt & 2,678 \\
& & $(2,76)^{* * *}$ \\
& Internet & 3,021 \\
& & $(2,68)^{* * *}$ \\
& Közvetlenül a termelőtöl & 2,059 \\
& & $(2,66)^{* * *}$ \\
& Egyéb alternatív & 5,316 \\
& & $(2,50)^{* *}$ \\
& Fogyaszt halat & 1,772 \\
& & $(2,81)^{* * *}$ \\
& Fogyaszt hústerméket & 0,408 \\
& $(2,34)^{* *}$ \\
& Fogyaszt tojást & 0,496 \\
& & $(1,73)^{*}$
\end{tabular}

Szignifikanciaszintek: * $p<0,1 ;{ }^{* *} p<0,05 ; * * * p<0,01$

Megjegyzés: esélyhányadosok, zárójelben az értékek. $A$ táblázat csak a szignifikáns eredményeket tartalmazza, a többi eredményért lásd az 1. sz. mellékletet.

Forrás: saját szerkesztés
Az EU biocímke életképességét leginkább az határozza meg, hogy a fogyasztók milyen gyakran hajlandók ilyen jelzéssel ellátott termékeket vásárolni (9. táblázat). A szociodemográfiai ismérvek közül egyedül a válaszadó életkora volt statisztikailag szignifikáns a modellben. Minél idősebb valaki, annál kisebb a valószínüsége, hogy rendszeres biovásárlóvá váljon. Ebből az a következtetés vonható le, hogy a biotermékeket forgalmazó vállalatoknak föként a fiatalabb generációkat kell megcélozniuk. A vásárlási helyszínek közül a szupermarketekben, diszkontokban, termelöi piacokon, áruházakban, hipermarketekben és a közvetlenül a termelőtől való vásárlás esetében válnak a fogyasztók a legnagyobb eséllyel rendszeres biovásárlóvá. Mindezek közül a legmagasabb eséllyel a szupermarketekben vásárlók lesznek rendszeres biofogyasztók. A leginkább számottevő mértékben a bizalom járul hozzá ahhoz, hogy egy vásárló gyakori biotermék-fogyasztóvá váljon: ha egy fogyasztó megbízik az EU biotanúsításban, akkor 6,7-szer nagyobb az esélye annak, hogy rendszeresen vásárol ilyen terméket, mint ha fenntartásai lennének a címkével kapcsolatban. Azt mindenképpen meg kell jegyezni, hogy az étrendnek nincs statisztikailag szignifikáns szerepe.

\section{9. táblázat A rendszeres vásárlást meghatározó tényezők}

\begin{tabular}{lll}
\hline $\begin{array}{l}\text { Rendszeres } \\
\text { vásárló }\end{array}$ & Életkor & 0,964 \\
& & $(2,02)^{* *}$ \\
& Szupermarket & 5,899 \\
& & $(2,82)^{* * *}$ \\
& Diszkont & $(2,589$ \\
& & 5,086 \\
& Termelői piac & $(2,85)^{* * *}$ \\
& 4,692 \\
& Áruház & $(2,39)^{* *}$ \\
& 4,084 \\
& Hipermarket & $(2,26)^{* *}$ \\
& 4,272 \\
& Közvetlenül a termelőtől & $(2,09)^{* *}$ \\
& & 6,692 \\
Bizalom & $(3,32)^{* * *}$
\end{tabular}

Szignifikanciaszintek: * $p<0,1 ; * * p<0,05 ; * * * p<0,01$ Megjegyzés: esélyhányadosok, zárójelben az értékek. A táblázat csak a szignifikáns eredményeket tartalmazza, a többi eredményért lásd az 1. sz. mellékletet.

Forrás: saját szerkesztés

\section{Összefoglalás}

\section{Elméleti következtetések}

Az Európai Unió által bevezetett biocímke egyrészt szabályozási oldalról hivatott igazolni, hogy a címkét viselő termék megfelel a jogszabályi kritériumoknak, továbbá - mint minden élelmiszercímke - a termékek minőségével kapcsolatos információs aszimmetriát próbálja csökkenteni. Éppen ezért a címke ismeretének mértéke nagymértékben meghatározza a rendszer létjogosultságát, illetve determinálja annak hatásosságát.

$\mathrm{Az}$ EU biocímke ismertsége hazánkban viszonylag alacsony, de növekvő tendencia figyelhető meg, és az 
utóbbi években már megközelíti az EU-s átlagot (Európai Bizottság, 2012, 2014, 2016), de messze elmarad a nyugat-európai országokban tapasztaltaktól (Janssen \& Hamm, 2012). A címke ismeretét föként a nem, az étrend és a vásárlás helyszíne határozza meg. Az eredményeink alapján a férfiak Magyarországon jobban ismerik a biocímkét, ellentétben a korábbi nemzetközi eredményekkel. Az étrendet, illetve a vásárlás helyszínét egyetlen korábbi tanulmány sem vizsgálta mélyrehatóan. Magyarországon a kutatás alapján az étrendet tekintve a rendszeres halfogyasztók és az (ovo-)vegetáriánusok ismerik jobban az EU biocímkét. Ez leginkább azzal magyarázható, hogy ezek a fogyasztók amúgy is tudatosabbak és tájékozottabbak a különböző élelmiszercímkékkel - így többek között a biotanúsítással - kapcsolatban is. Továbbá kiemelendő, hogy a logót tekintve azon vásárlók tájékozottabbak, akik termelői piacokon, áruházakban, bioboltokban, online, közvetlenül a termelőtől, vagy egyéb, alternatív csatornákon keresztül vásárolnak élelmiszert. Ez egybecseng korábbi magyarországi vizsgálatokkal is, miszerint a magyar bioélelmiszerek kínálati oldalán az ökopiacoknak van meghatározó szerepük a bioboltok mellett (Szente, 2006).

Fontos ugyanakkor hangsúlyozni, hogy a vásárlók többnyire nem veszik figyelembe, hogy az adott termék el van-e látva valamilyen minőségi tanúsítvánnyal, köszönhetően főként a vásárlásra fordított időnek, illetve annak, hogy kevés figyelmet fordítanak az élelmiszereken megjelenő jelölésekre. Ez önmagában megkérdőjelezi, hogy a biotanúsítás elérheti-e a kitűzött céljait a fogyasztók körében, hiszen azon, hogy a fogyasztó ritkán veszi figyelembe a jelöléseket, illetve nincs ideje ezekkel foglalkozni; nem, vagy csak nagyon nehezen lehet változtatni.

\section{Menedzseri következtetések}

Ugyan a biotanúsítás egy kötelező jelölés, amennyiben az élelmiszert bioként kívánják értékesíteni, egyfajta marketinglehetőséget is jelenthet, hiszen az EU biologó (kiegészülve a magyarországi tanúsító szervezetek logójával) pozitív asszociációt jelenthet a fogyasztó számára.

Mivel a biocímke az EU egész területén kötelező, s a címkehasználatra kollektíven jogosult minden termelő és feldolgozó, aki a feltételeknek megfelel, így joggal várható el a címke marketingjének közösségi finanszírozása. Az Európai Bizottság mezőgazdasági termékek és élelmiszerek promóciójára hivatott szervezete (CHAFEA - Fogyasztó-, Egészség-, Élelmiszerügyi és Mezőgazdasági Végrehajtó Ügynökség) az elmúlt öt évben összesen 21 különböző olyan kampányt finanszírozott közel ötvenmillió euró értékben, amelynek célja részben, vagy teljes egészében az EU biocímke ismertségének növelésére irányult. Ezeknek a kampányoknak több mint egyharmada EU-n kívüli országo(ka)t célzott meg, míg Magyarországra mindösszesen egyetlen kezdeményezés irányult (CHAFEA, 2019). Ezek alapján megállapítható, hogy a közeljövöben jelentős költségvetésü, EU által finanszírozott és a közösségi biocímke ismertségének növelésére irányuló marketingkampány nem várható Magyarországon.
Felmérésünk eredményeként továbbá megállapítható, hogy azon magyar fogyasztók, akik ismerik a tanúsítást valamennyien igen pozitív véleménnyel rendelkeznek összességében a biocímkével kapcsolatban és megbízhatónak találják azt. Ez azért fontos, mert eredményeink szerint a címkébe vetett bizalom dönti el leginkább, hogy az adott fogyasztó rendszeres vásárlójává válik-e a bioterméknek.

Kutatásunk alapján az életkornak is meghatározó szerepe van abban, hogy valaki rendszeresen vásárol-e biotanúsítással ellátott termékeket: minél idősebb egy magyar fogyasztó, várhatóan annál kisebb lesz ennek az esélye.Ez alapján a fiatalok nagyobb valószínüséggel válnak rendszeres bioélelmiszer fogyasztóvá, tehát a vállalatoknak fóként őket kell megszólítaniuk. Ez összhangban van az európai tendenciákkal is, miszerint az ilyen típusú élelmiszereket egyre inkább a fiatalabbak keresik. Mindezek alapján megállapítható, hogy a jelenlegi fogyasztásnál lényegesen nagyobb piaci volumen érhető el a biotermékek megfelelő pozicionálásával.

A magyar piacon a legnépszerűbb biotanúsítással ellátott termékek a friss gyümölcs- és zöldségfélék, valamint a gabonafélék termékcsoportjából kerülnek ki, jelentős mértékben importból, hiszen a magyarországi organikus termelésbe vont területek aránya nem ezt indokolná. Ez a bioélelmiszer import létjogosultságát támasztja alá, $\mathrm{s}$ ezeknek az élelmiszer-kereskedőknek elsősorban a szuper- és hipermarketeket, az élelmiszerdiszkontokat kell megcélozniuk, hiszen ezeken a csatornákon keresztül érhetik el a leghatékonyabban a potenciális törzsvásárlókat. Ugyanakkor a kisebb méretű magyarországi biotermelök és -feldolgozók elsődleges értékesítési csatornája továbbra is a rövid ellátási láncok között keresendő: a termelői piacokon (elsősorban az ökopiacokon), illetve közvetlen értékesítéssel tudják elérni a legnagyobb valószínüséggel a potenciális vásárlóközönségüket.

\section{A kutatás korlátai és jövőbeli kutatási irányok}

Ugyan a kutatásunk több szempontból hiánypótlónak számít Magyarországon - hiszen ezt a kérdéskört mindezidáig nem, vagy csak régebben vizsgálták -, a kapott eredmények értelmezésénél mindenképpen figyelembe kell venni, hogy az online adatfelvétel miatt a felhasznált minta csak a nemek és az életkor tekintetében reprezentatív és különösen a lakóhely, az iskolai végzettség, valamint a családméret szempontjából torzított.

Kutatásunk egyik központi kérdését - mennyire ismerik a magyar fogyasztók az EU biocímkéjét - érdemes a későbbiekben is megvizsgálni, s az Európai Bizottság rendszeres, ugyanakkor meglehetősen felületes lekérdezésén túl alaposabban is elemezni az összefüggéseket. Továbbá különösen menedzsmentszempontból érdemes azt vizsgálni, hogy az EU biocímkével ellátott termékeket mekkora árprémiummal lehet értékesíteni Magyarországon. A fogyasztók fizetési határhajlandóságának mérése még fontosabb információkat biztosíthatnának a bioélelmiszerek piacán érintett szereplők számára. 


\section{Felhasznált irodalom}

Aarset, B., Beckmann, S., Bigne, E., Beveridge, M., Bjorndal, T., Bunting, J., McDonagh, P., ... Young, J. (2004). The European consumers' understanding and perceptions of the "organic" food regime: The case of aquaculture. British Food Journal, 106(2), 93-105. https://doi.org/10.1108/00070700410516784

Anania, G. \& Nisticò, R. (2004). Public regulation as a substitute for trust in quality food markets: What if the trust substitute cannot be fully trusted? Journal of Institutional and Theoretical Economics, 160(4), 681-701. https://doi.org/10.1628/0932456042776113

Andersen, E. S. (1994). The evolution of credence goods: A transaction approach to product specification and quality control. MAPP - Centre for Research on Customer Relations in the Food Sector. https://pure.au.dk/ portal/en/publications/the-evolution-of-credencegoods-a-transaction-approach-to-product-specification-and-quality-control(53ab4d10-b80a-11da-ad69000ea68e967b).html

Barber, N., Taylor, D. C., \& Deale, C. S. (2010). Wine tourism, environmental concerns, and purchase intention. Journal of Travel and Tourism Marketing, 27(2), 146165. https://doi.org/10.1080/10548400903579746

Európai Bizottság (2012). Europeans' attitudes towards food security, food quality and the countryside. http:// ec.europa.eu/public_opinion/archives/ebs/ebs_389 en.pdf

Európai Bizottság (2014). Europeans, Agriculture and the Common Agricultural Policy (CAP). http://ec.europa. eu/public_opinion/archives/ebs/ebs_410_en.pdf

Európai Bizottság (2016). Europeans, Agriculture and the CAP. http://ec.europa.eu/commfrontoffice/publicopinion/index.cfm/ResultDoc/download/Document$\mathrm{Ky} / 69756$

Bonroy, O. \& Constantatos, C. (2015). On the economics of labels: How their introduction affects the functioning of markets and the welfare of all participants. American Journal of Agricultural Economics, 97(1), 239-259. https://doi.org/10.1093/ajae/aau088

Bruschi, V., Shershneva, K., Dolgopolova, I., Canavari, M., \& Teuber, R. (2015). Consumer Perception of Organic Food in Emerging Markets: Evidence from Saint Petersburg, Russia. Agribusiness, 31(3), 414-432. https://doi.org/10.1002/agr.21414

CHAFEA(2019). Promotion of agricultural products - Campaigns map and statistics. Letöltve: https://ec.europa. eu/chafea/agri/campaigns/map-and-statistics-target-countries?field_year_value[min] $=2005 \&$ field_ year_value $[\mathrm{max}]=2035 \&$ field_program_type_ value $=$ All\&field_quality_schemes_tid[] $=237 \&$ field eu_organisation_value $=A \overline{1} 1 \&$ items_per_page $=40$

Davies, A., Titterington, A. J., \& Cochrane, C. (1995). Who buys organic food? A profile of the purchasers of organic food in Northern Ireland. British Food Journal, 97(10), 17-23. https://doi.org/10.1108/00070709510104303

Dörnyei, K. (2008). Bioélelmiszer-fogyasztási szokások: Szegmentálás és a bizalom fontossága. Marketing \& Menedzsment, 42(4), p. 34-42.
Fernqvist, F. \& Ekelund, L. (2014). Credence and the effect on consumer liking of food - A review. Food Quality and Preference, 32, 340-353. https://doi.org/10.1016/j. foodqual.2013.10.005

FiBL (2019). Data on organic agriculture in Europe. https://statistics.fibl.org/europe.html

Fotopoulos, C. \& Krystallis, A. (2002a). Organic product avoidance: Reasons for rejection and potential buyers' identification in a countrywide survey. British Food Journal, 104, 233-260. https://doi.org/10.1108/00070700210425697

Fotopoulos, C. \& Krystallis, A. (2002b). Purchasing motives and profile of the Greek organic consumer: A countrywide survey. British Food Journal, 104(9), 730-765. https://doi.org/10.1108/00070700210443110

Gál, T., Soós, M., \& Szakály, Z. (2017). Egészségtudatos táplálkozással kapcsolatos fogyasztói insight-ok feltárása netnográfiával - esettanulmány. Vezetéstudomány, 48(4), 46-54. https://doi.org/10.14267/VEZTUD.2017.04.07

Gergely, É., Szabó, B., \& Balázs, K. (2014). Az egészség- és környezettudatosság, valamint az értékrend hatása a bioélelmiszer-fogyasztásra. Marketing \& Menedzsment, 48(4).

Giannakas, K. (2002). Information asymmetries and consumption decisions in organic food product markets. Canadian Journal of Agricultural Economics, 50(1), 3550. https://doi.org/10.1111/j.1744-7976.2002.tb00380.x

Goldman, B. J. \& Clancy, K. L. (1991). A survey of organic produce purchases and related attitudes of food cooperative shoppers. American Journal of Alternative Agriculture, 6(2), 89-96. https://doi.org/10.1017/S0889189300003933

Hartmann, M., Yeh, C.-H., Amilien, V., Čeliković, Z., Csillag, P., Filipović, J., Giraud, G., ... Veneziani, M. (2018). Quantitative research findings on European consumers' perception and valuation of EU food quality schemes as well as their confidence in such measures. https://www. strength2food.eu/2018/03/07/report-quantitative-research-findings-european-consumers-perception-valuation-eu-food-quality-schemes-well-confidence-measures/

Hemmerling, S., Hamm, U., \& Spiller, A. (2015). Consumption behaviour regarding organic food from a marketing perspective - a literature review. Organic Agriculture, 5(4), 277-313.

Hill, H. \& Lynchehaun, F. (2002). Organic milk: Attitudes and consumption patterns. British FoodJournal, 104(7), 526-542. https://doi.org/10.1108/00070700210434570

Hofer, M. (2009). Bioélelmiszerek fogyasztásának tendenciája Magyarországon (Doktori értekezés). Széchenyi István Egyetem, Győr.

Horváth, Á., Kovács, A., \& Gyenge, B. (2003). A vásárlók biotermékekkel szembeni attitüdje a hiper- és szupermarketekben. Marketing \& Menedzsment, 37(6), 23-34.

Hutchins, R. K. \& Greenhalgh, L. A. (1997). Organic confusion: Sustaining competitive advantage. British Food Journal, 99(9), 336-338. https://doi. org/10.1108/00070709710193998

Janssen, M. \& Hamm, U. (2012). Product labelling in the market for organic food: Consumer preferences and willingness-to-pay for different organic certification logos. Food Quality and Preference, 25(1), 9-22. https://doi.org/10.1016/j.foodqual.2011.12.004 
Kiss, C., Vincze, J., Tenk, A., Paszthy, G., \& Toaso, S. (2005). Fogyasztói vélemények a bio-sertéshúsról, illetve a sertéshúsfogyasztásról. Gazdálkodás, 49, 7.

Kiss, M., Kontor, E., \& Kun, A. I. (2016). Az organikuscímke-hatás a marketing irodalomban: imázstranszfer, halo-hatás és jelzés. Táplálkozásmarketing, 3(1), 61-71.

Koivisto Hursti, U. K. \& Magnusson, M. K. (2003). Consumer perceptions of genetically modified and organic foods. What kind of knowledge matters? Appetite, 41(2), 207-209. https://doi.org/10.1016/S0195-6663(03)00056-4

KSH (2013). Népszámlálás 2011. Letöltve: http://www. ksh.hu/nepszamlalas/reszletes_tablak

KSH (2019). Biogazdálkodás. Letöltve: http://www.ksh. $\mathrm{hu} /$ docs/hun/xstadat/xstadat_eves/i_ua001a.html

Lea, E. \& Worsley, T. (2005). Australians' organic food beliefs, demographics and values. British Food Journal, 107(11), 855-869. https://oi. org/10.1108/00070700510629797

Lockie, S., Lyons, K., Lawrence, G., \& Mummery, K. (2002). Eating 'green': Motivations behind organic food consumption in Australia. Sociologia Ruralis, 42(1), 23-40. https://doi.org/10.1111/1467-9523.00200

Loureiro, M. L. (2003). Rethinking new wines: Implications of local and environmentally friendly labels. Food Policy, 28(56), 547-560. https://doi.org/10.1016/j.foodpol.2003.10.004

Magnusson, M. K., Arvola, A., Hursti, U. K. K., Åberg, L., \& Sjödén, P. O. (2003). Choice of organic foods is related to perceived consequences for human health and to environmentally friendly behaviour. Appetite, 40(2), 109-117. https://doi.org/10.1016/S0195-6663(03)00002-3

Magnusson, M. K., Arvola, A., Koivisto Hursti, U. K., Åberg, L., \& Sjödén, P. O. (2001). Attitudes towards organic foods among Swedish consumers. British Food Journal, 103(3), 209-227. https://doi. org/10.1108/00070700110386755

Malota, E., Gyulavári, T., \& Bogáromi, E. (2019). „Az vagy, amit megeszel" A hazai fogyasztók egészséges táplálkozással kapcsolatos percepciói és attitüdjei. Vezetéstudomány, 50(1), 80-88. https://doi.org/10.14267/VEZTUD.2019.01.08

Mann, S., Ferjani, A., \& Reissig, L. (2012). What matters to consumers of organic wine? British Food Journal, 114(2), 272-284. https://doi. org/10.1108/00070701211202430

McEachern, M. G. \& McClean, P. (2002). Organic purchasing motivations and attitudes: Are they ethical? International Journal of Consumer Studies, 26(2), 85-92. https://doi.org/10.1046/j.1470-6431.2002.00199.x

McEachern, M. G. \& Willock, J. (2004). Producers and consumers of organic meat: A focus on attitudes and motivations. British Food Journal, 106(7), 534-552. https://doi.org/10.1108/00070700410545737

O'Donovan, P. \& McCarthy, M. (2002). Irish consumer preference for organic meat. British Food Journal, 104, 353-370. https://doi.org/10.1108/00070700210425778

Panyor, Á. (2010). Az organikus édesipari termékek fogyasztási szokásainak elemzése. Élelmiszer, Táplákozás és Marketing, 7(1), 21-25.

Podruzsik, S. \& Hegede, G. (2019). Az online marketing szerepe az információkeresésben bioélelmiszereknél.
Élelmiszer, Táplálkozás és Marketing, 13(1), 11-17. https://doi.org/10.33567/etm.2255

Pomarici, E. \& Vecchio, R. (2014). Millennial generation attitudes to sustainable wine: An exploratory study on Italian consumers. Journal of Cleaner Production, 66, 537-545. https://doi.org/10.1016/j.jclepro.2013.10.058

Radman, M. (2005). Consumer consumption and perception of organic products in Croatia. British Food Journal, 107(4), 263-273. https://doi. org/10.1108/00070700510589530

Roddy, G., Cowan, C. A., \& Hutchinson, G. (1996). Consumer attitudes and behaviour to organic foods in Ireland. Journal of International Consumer Marketing, 9(2), 41-63. https://doi.org/10.1300/J046v09n02_03

Sandalidou, E., Baourakis, G., \& Siskos, Y. (2002). Customers' perspectives on the quality of organic olive oil in Greece: A satisfaction evaluation approach. British Food Journal, 104, 391-406. https://doi. org/10.1108/00070700210425787

Schäufele, I. \& Hamm, U. (2017). Consumers' perceptions, preferences and willingness-to-pay for wine with sustainability characteristics: A review. Journal of Cleaner Production, 147, 379-394. https://doi. org/10.1016/j.jclepro.2017.01.118

Schifferstein, H. N. J. \& Oude Ophuis, P. A. M. (1998). Health-related determinants of organic food consumption in the Netherlands. Food Quality and Preference, 9(3), 119133. https://doi.org/10.1016/S0950-3293(97)00044-X

Schleenbecker, R. \& Hamm, U. (2013). Consumers' perception of organic product characteristics. A review. Appetite, 71, 420-429. https://doi.org/10.1016/j.appet.2013.08.020

Sønderskov, K. M. \& Daugbjerg, C. (2011). The state and consumer confidence in eco-labeling: Organic labeling in Denmark, Sweden, The United Kingdom and The United States. Agriculture and Human Values, 28(4), 507-517. https://doi.org/10.1007/s10460-010-9295-5

Stobbelaar, D. J., Casimir, G., Borghuis, J., Marks, I., Meijer, L., \& Zebeda, S. (2007). Adolescents' attitudes towards organic food: A survey of 15- to 16-year old school children. International Journal of Consumer Studies, 31(4), 349-356. https://doi.org/10.1111/j.1470-6431.2006.00560.x

Storstad, O. \& Bjørkhaug, H. (2003). Foundations of production and consumption of organic food in Norway: Common attitudes among farmers and consumers? Agriculture and Human Values, 20(2), 151-163. https:// doi.org/10.1023/A:1024069627349

Szabó, E. (2006). Az eredet- és minöségjelzők alkalmazásának lehetöségei és feltételei a marketingkommunikációban (Doktori értekezés). Budapesti Corvinus Egyetem, Budapest.

Szente, V. (2004). Organikus élelmiszerek fogyasztási és vásárlási szokásainak vizsgálata Magyarországon. Élelmiszer, Táplákozás és Marketing, 1(1-2), 1-10.

Szente, V. (2005). Az ökoélelmiszerek termelésének, kereskedelmének gazdasági és piaci összefüggései (Doktori értekezés). Kaposvári Egyetem, Kaposvár.

Szente, V. (2006). Tendenciák az ökoélelmiszerek fogyasztásában és értékesítésében. Élelmiszer, Táplákozás és Marketing, 3(1), 6. 
Szente, V. (2009). A bizalom megítélése az ökoélelmiszerek piacán. Élelmiszer, Táplákozás és Marketing, 6(1-2).

Thompson, G. D. \& Kidwell, J. (1998). Explaining the choice of organic produce: Cosmetic defects, prices, and consumer preferences. American Journal of Agricultural Economics, 80(2), 277-287. https://doi.org/10.2307/1244500

Vecchio, R. (2013). Determinants of willingness-to-pay for sustainable wine: Evidence from experimental auctions. Wine Economics and Policy, 2(2), 85-92. https:// doi.org/10.1016/j.wep.2013.11.002

Wandel, M. \& Bugge, A. (1997). Environmental concern in consumer evaluation of food quality. Food Quality and Preference, 8(1), 19-26. https://doi.org/10.1016/ S0950-3293(96)00004-3
Wilkins, J. L. \& Hillers, V. N. (1994). Influences of pesticide residue and environmental concerns on organic food preference among food cooperative members and non-members in Washington State. Journal of Nutrition Education, 26(1), 26-33. https://doi.org/10.1016/S0022-3182(12)80831-4

Yiridoe, E. K., Bonti-Ankomah, S., \& Martin, R. C. (2005). Comparison of consumer perceptions and preference toward organic versus conventionally produced foods: A review and update of the literature. Renewable $\mathrm{Ag}$ riculture and Food Systems, 20(4), 193-205. https://doi. org/10.1079/RAF2005113

Zander, K. (2014). A Green Leaf!? Consumers' Knowledge and Perception of the Mandatory EU Organic Logo. Proceedings in Food System Dynamics, 220-228. 
1. melléklet A logisztikus regressziós modellek eredményei

\begin{tabular}{|c|c|c|}
\hline \multirow[t]{20}{*}{ Ismeri az EU biocímkét } & Nem & $\begin{array}{l}0,660 \\
(2,33)^{* *}\end{array}$ \\
\hline & Gyermekek száma & $\begin{array}{l}1,088 \\
(0,96)\end{array}$ \\
\hline & Életkor & $\begin{array}{l}0,997 \\
(0,44)\end{array}$ \\
\hline & Képzettség & $\begin{array}{l}0,979 \\
(0,21)\end{array}$ \\
\hline & Lakóhely & $\begin{array}{l}1,080 \\
(0,62)\end{array}$ \\
\hline & Jövedelem & $\begin{array}{l}0,961 \\
(0,77)\end{array}$ \\
\hline & Szupermarket & $\begin{array}{l}1,468 \\
(1,62)\end{array}$ \\
\hline & Diszkont & $\begin{array}{l}1,253 \\
(0,88)\end{array}$ \\
\hline & Kisbolt & $\begin{array}{l}1,398 \\
(1,56)\end{array}$ \\
\hline & Termelői piac & $\begin{array}{l}1,716 \\
(2,49) * *\end{array}$ \\
\hline & Áruház & $\begin{array}{l}1,661 \\
(2,14)^{* *}\end{array}$ \\
\hline & Hipermarket & $\begin{array}{l}1,257 \\
(1,07)\end{array}$ \\
\hline & Biobolt & $\begin{array}{l}2,678 \\
(2,76)^{* * *}\end{array}$ \\
\hline & Internet & $\begin{array}{l}3,021 \\
(2,68)^{* * *}\end{array}$ \\
\hline & Közvetlenül a termelötől & $\begin{array}{l}2,059 \\
(2,66)^{* * *}\end{array}$ \\
\hline & Egyéb alternatív & $\begin{array}{l}5,316 \\
(2,50) * *\end{array}$ \\
\hline & Fogyaszt tejterméket & $\begin{array}{l}1,054 \\
(0,12)\end{array}$ \\
\hline & Fogyaszt halat & $\begin{array}{l}1,772 \\
(2,81)^{* * *}\end{array}$ \\
\hline & Fogyaszt hústerméket & $\begin{array}{l}0,408 \\
(2,34)^{* *}\end{array}$ \\
\hline & Fogyaszt tojást & $\begin{array}{l}0,496 \\
(1,73)^{*}\end{array}$ \\
\hline \multirow[t]{22}{*}{ Rendszeres vásárló } & Nem & $\begin{array}{l}2,006 \\
(1,56)\end{array}$ \\
\hline & Gyermekek száma & 0,850 \\
\hline & Életkor & $\begin{array}{l}0,964 \\
(2,02)^{* *}\end{array}$ \\
\hline & Képzettség & $\begin{array}{l}1,253 \\
(0,89)\end{array}$ \\
\hline & Lakóhely & $\begin{array}{l}0,944 \\
(0,19)\end{array}$ \\
\hline & Jövedelem & $\begin{array}{l}0,815 \\
(1,56)\end{array}$ \\
\hline & Szupermarket & $\begin{array}{l}5,899 \\
(2,82)^{* * *}\end{array}$ \\
\hline & Diszkont & $\begin{array}{l}4,589 \\
(2,14)^{* *}\end{array}$ \\
\hline & Kisbolt & $\begin{array}{l}2,471 \\
(1,44)\end{array}$ \\
\hline & Termelöi piac & $\begin{array}{l}5,086 \\
(2,85)^{* * *}\end{array}$ \\
\hline & Áruház & $\begin{array}{l}4,692 \\
(2,39)^{* *}\end{array}$ \\
\hline & Hipermarket & $\begin{array}{l}4,084 \\
(2,26)^{* *}\end{array}$ \\
\hline & Biobolt & $\begin{array}{l}1,862 \\
(0,82)\end{array}$ \\
\hline & Internet & $\begin{array}{l}0,615 \\
(0,57)\end{array}$ \\
\hline & Közvetlenül a termelötől & $\begin{array}{l}4,272 \\
(2,09)^{* *}\end{array}$ \\
\hline & Egyéb alternatív & $\begin{array}{l}10,814 \\
(1,42)\end{array}$ \\
\hline & Fogyaszt tejterméket & $\begin{array}{l}0,473 \\
(0,76)\end{array}$ \\
\hline & Fogyaszt halat & $\begin{array}{l}1,726 \\
(1,02)\end{array}$ \\
\hline & Fogyaszt hústerméket & $\begin{array}{l}0,694 \\
(0,49)\end{array}$ \\
\hline & Fogyaszt tojást & $\begin{array}{l}0,436 \\
(0,81)\end{array}$ \\
\hline & Ismeret & $\begin{array}{l}0,516 \\
(1,04)\end{array}$ \\
\hline & Bizalom & $\begin{array}{l}6,692 \\
(3,32) * * *\end{array}$ \\
\hline
\end{tabular}

Szignifikanciaszintek: * $p<0,1 ;{ }^{* *} p<0,05 ; * * * p<0,01$

Megjegyzés: esélyhányadosok, zárójelben a z értékek

Forrás: saját szerkesztés 